УДК 94(477.74-25)«1918»

\section{Тарас Вінцковський}

доктор історичних наук, професор кафедри історії України Одеського начіонального університету імені I. I. Мечникова

\section{КРИВАВИЙ «АЛМАЗ»: ДЕ/КОНСТРУКЦІЯ ОДНОГО МІФУ РЕВОЛЮЦІЇ В ОДЕСІ}

Усічні 1918р. в Одесі відбулося більшовииькезбройнеповстання, активну участь в підготовиі якого відіграла команда крейсера «Алмаз». У період існування Одеської радянської республіки нова влада використовувала практику «червоного» терору, символом якого став «Алмаз». Внаслідок затримання і фізичної ліквідації на крейсері та в місиях стоянок інших військових кораблів представників різних категорій населення, відтак потирення найрізноманітніших чуток, органи міського самоврядування намагалися взяти під контроль ситуачію, щоб унеможливити факти самосуду. Але повною мірою з'ясовувати обставини утримання в'язнів та їхню подальшу долю судово-слідчі інституиії змогли лише після відновлення влади УНР в Одесі. Їхні висновки розвінчують створений радянською історіографією геройчний образ крейсера.

Ключові слова: революиія, УНР, Одеса, більшовики, «червоний» терор, крейсер «Алмаз», міська дума, Одеська украйнська міська рада.

1 Загоруйко, В. (11.11.1962). «Південна «Аврора». У Чорноморська комуна..

2 Держархів Одеської області, Ф. П-13, Оп. 2, спр. 118, арк. 1.

${ }^{3}$ Коновалов, В. (1963). Подвиг «Алмаза». Одеса: Одесское книжное издательство, С. 6.

${ }^{4}$ Коновалов, В. (1989). Подвиг «Алмаза»: документальная повесть. 2-е изд., перераб. и дОп. Одеса: Маяк.

${ }^{5}$ Там же, С. 167. $\prod_{\text {ки імен }}$

о 45-річчя встановлення більшовицької влади у Петрограді в одеській газеті «Чорноморська комуна» була опублікована стаття директора Одеської державної наукової бібліотеки імені О. М. Горького В. Загоруйка, в якій автор анонсував вихід у світ книги одеського історика В. Коновалова, присвяченій участі крейсера «Алмаз» у революції на півдні України, котра найімовірніше мала отримати назву «Південна «Аврора»»» ${ }^{1}$, що підтверджується й стенограмою обговорення праці наступного року після іiі появи в продажі ${ }^{2}$. Дійсно у 1963 р. в книгарнях СРСР з'явилася документальна повість під назвою «Подвиг «Алмаза»»), метою котрої стало продемонструвати «видатну роль, яку зіграли екіпаж крейсера «Алмаз» і чорноморські моряки в боротьбі за встановлення і зміцнення Радянської влади в Одесі»³.

В. Коновалов через 26 років перевидав свою працю, в якій знову підкреслював винятковість матросів бойового корабля у встановленні більшовицької влади в Одесі, в протистоянні зі збройними силами УНР та загалом «внутрішніх і зовнішніх контрреволюційних сил» ${ }^{4}$ В очах дослідника статус «Алмаза» додатково підвищувався тим фактом, що на ньому у січні - березні 1918 р. розташовувався штаб морських сил (з 25 лютого командувач А. Желєзняков), які діяли проти румунських військ ${ }^{5}$. Вони 
${ }^{6}$ Шкляев, И. Н. (2002). История Одесской ГУБЧК. 19171922 гг. Одесса: Студія «Негоціант», С. 33; Його ж. (2004). Одесса в смутное время. Одесса: Студия «Негоціант», С. 85.

${ }^{7}$ (2002). Гражданская война в России: Черноморский флот. М.: ООО «Издательство АСТ»; Мисечко, А. І. (2006). До історії українського козацтва в Одесі в період діяльності Центральної Ради (березень 1917 квітень 1918 рр.). У Записки історичного факультету. Одеський національний університет імені I. I. Мечникова. Bun. 17. Одеса: Астропринт, С. 191-196; ФайтельбергБланк, В., Савченко, В. (2008). Одесса в эпоху войн и революцій. 1914-1920. - Одесса: Изд-во «Optimum»; Шишко, О. Г. (2011). «Одеська радянська республіка»: політика терору. У Інтелігенція $і$ влада. Громадсько-політичний науковий збірник. Серія: Історія. Вип. 22. Одеса: Астропринт, С. 168178; Його ж. (2012). Диктатура Муравйова в Одесі. У Інтелігенція і влада. Громадсько-політичний науковий збірник. Серія: Історія. Bun. 24. Одеса: Астропринт, С. 218-229; Поплавський, О. О. (2012). Репресії і терор як основа більшовицької влади в новостворених радянських республіках Півдня України на початку 1918 р. У Наукові праці історичного факультету Запорізького національного університету. Вип. XXXIII. Запоріжжя: ЗНУ, С. 80-86; Гриценко, І. В. (2015). Український державний флот в 1917-1919 рр.: історія його становлення, військово-політичної боротьби та занепаду. К.: Видавець Олег Філюк.

${ }^{8}$ Гриценко, I. В. Вказ.праця. C. 71 .

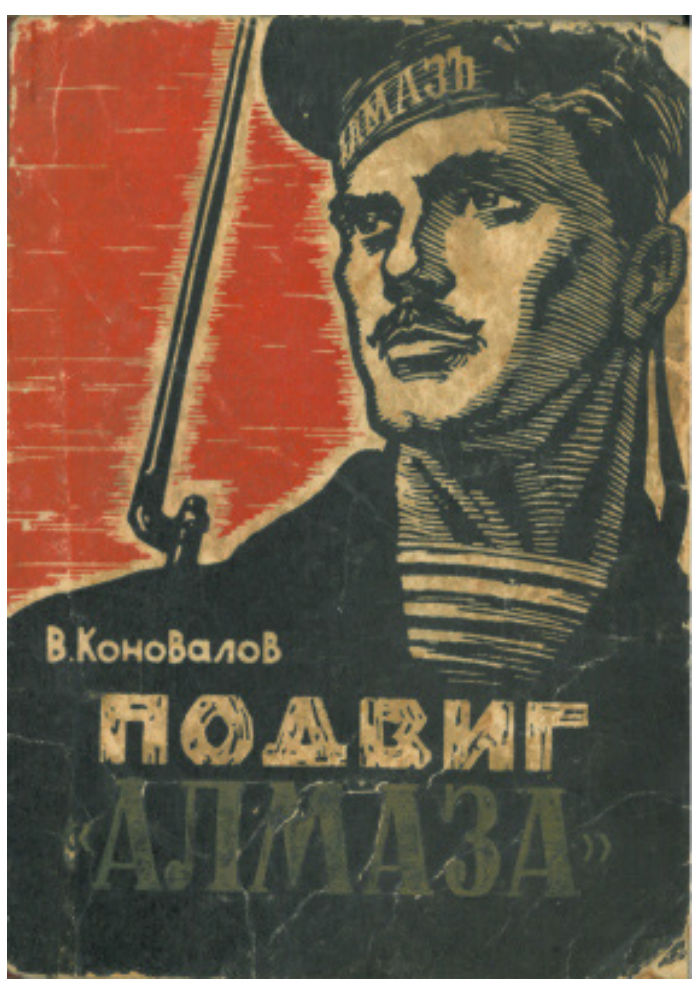

якраз у цей час взяли під контроль Бессарабію й просувалися в бік Одеси, що трактувалося у міському середовищі як реальна загроза збройного зіткнення.

У новітніх спеціальних і краєзнавчих дослідженнях окреслена проблематика не викликала особливого зацікавлення. Варто скоріше констатувати наявність лаконічних запозичень 3 праць попередників, доповнених інформацією, котра наразі не підтверджується джерелами. Зокрема, можна навести тези одеського історика I. Шкляєва про участь австрійського й німецького командування в проведенні розслідування можливих злочинів на крейсері «Алмаз» ${ }^{6}$.

Не ставили перед собою за мету заглибитися у специфічний аспект й інші автори, для яких окреслена тема не стала предметом окремого дослідження7. Вони здебільшого побіжно розглядали сюжетні лінії пов'язані з репресіями на військових пароплавах, відновлювали частину імен загиблих й загалом підтверджували значення даної категорії військовослужбовців у поширенні більшовицької влади в регіоні. Найбільш випукло реконструював формування специфічного іміджу крейсера ще один одеський дослідник О. Шишко, який детально проаналізував місцеву пресу. А його запорізький колега I. Гриценко навів оригінальні пояснення капітана першого рангу князя Я. Туманова щодо пальми першості у встановленні «червоного» терору в Одесі, яка на його думку належала саме «Алмазу». Адже він для міста був «кораблем-пришельцем», а лінкор «Синоп», який теж активно фігурував у чутках про звірства більшовиків, більше часу стояв на одеському рейді, встиг стати своїм і начебто нелегально став на службу крупній єврейській буржуазії, рятуючи іiі від загибелі за солідну винагороду ${ }^{8}$.

Значення крейсера у підготовці та здійсненні більшовицького збройного повстання 27-30 (14-17) січня 1918 р. не викликає сумнівів. У даній розвідці ми ставимо перед собою іншу мету - ви- 
Крейсер «Алмаз»

${ }^{9}$ Коновалов, В. (1963). Подвиг «Алмаза». Одеса: Одесское книжное издательство, С. 6; Пилишенко, В. (1977). Чорноморці в Українській революції. У Альманах Украӥнського народного союзу на 1977 рік. Річник 67. Джерсі Сіті-НьюЙорк: Видавництво «Свобода», C. 27.

10 Держархів Одеської області, Ф. П-13, Оп. 3, Спр. 8, Арк. 1, 3,4 .

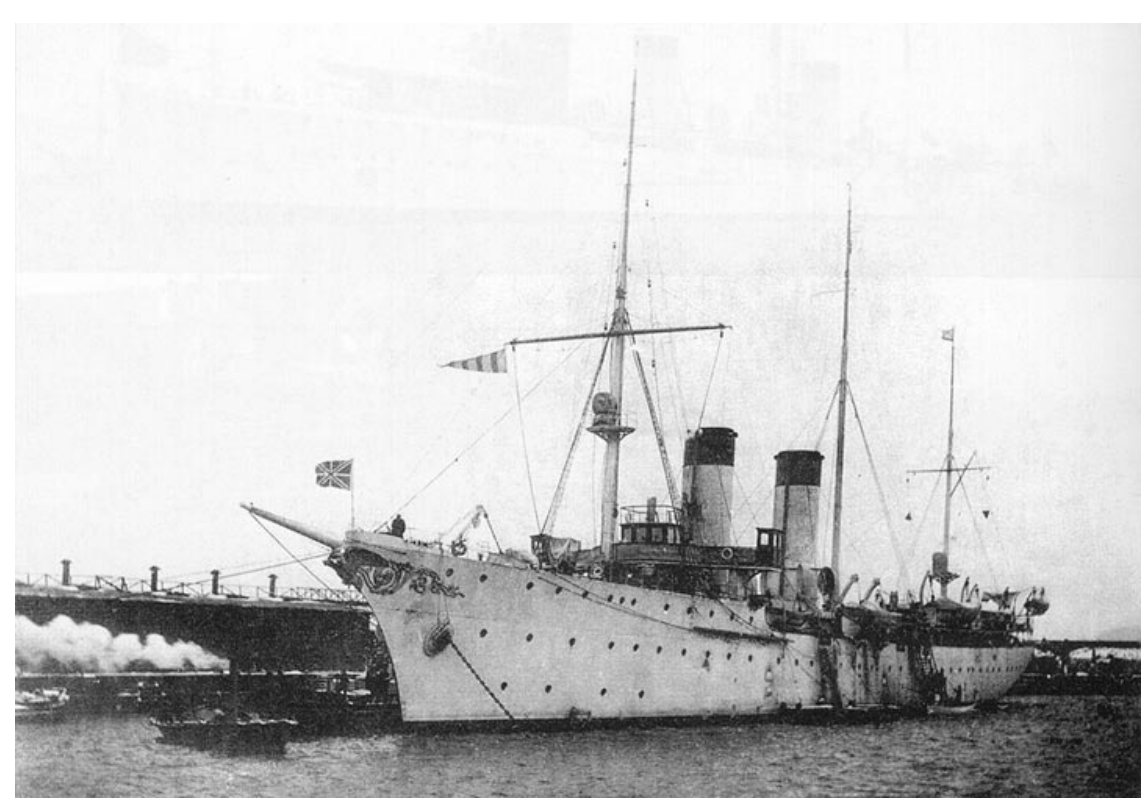

світлити роль корабля у розгортанні «червоного» терору, оскільки саме на його борту було організовано одну 3 в'язниць, куди відправляли як ідейних противників РСДРП(б), так і випадкових осіб, яких або підозрювали у контрреволюційних намірах, або у буржуазному походженні. Прикметно, що ще протягом тривалого проміжку часу з уст в уста одеситів передавалася сумна приказка «Ой, яблочко, куда катишься, на «Алмаз» попадешь - не воротишься!» ${ }^{9}$. За однією 3 версій її переробили з української пісенної традиції «Ой, яблучко, куди ж котишся? Пусти мати на вулицю, гулять хочеться!». Для реалізації поставленої мети слід виконати наступні завдання - проаналізувати увесь комплекс наявних джерел, з'ясувати обставини реалізації репресивних заходів щодо затриманих більшовицькою владою осіб, проаналізувати ставлення населення та місцевої влади до проблеми, встановити кількість жертв та місця їхнього поховання.

Розповідь про репресії на «Алмазі» була б неповною, якщо хоча б побіжно не згадати про загальне тло подій в Одесі. Протягом грудня 1917 р. - січня 1918 р. більшовицькі активісти та їх симпатики активно готувалися до реалізації силового сценарію встановлення своєї влади. До безпосереднього втілення в життя окресленого плану Військово-революційний комітет на чолі 3 В. Юдовським приступив у ніч проти 27 (14) січня 1918 р. Збройне протистояння 3 підрозділами армії УНР тривало до 30 (17) січня й закінчилося проголошенням Одеської радянської республіки.

Перші заарештовані почали надходити на «Алмаз» ще до початку вуличних боїв в місті про що свідчать джерела особового походження. Наприклад, заступник голови корабельного комітету, член «трійки по боротьбі з контрреволюцією» (до неї також увійшли голова корабельного комітету й «трійки» П. Кондренко і П. Скворченко) крейсера та РСДРП(б) М. Аркушенко розповідав про відправку на «Алмаз» частини офіцерів Охтирського кавалерійського полку, де їх згодом знищили, а також про рішення корабельного комітету ув'язнювати «контрреволюційні елементи» ${ }^{10}$. 
${ }^{11}$ Омелянович-Павленко, М. (2002). Спогади українського командарма. К.: Планета людей, С. 56.

${ }^{12}$ Гришко, Г. (1930). 1917 рік в Одесі (Спомини з часів визвольних змагань) У Розбудова націiі. Ч. 11-12. С. 291-292.

${ }^{13}$ Там само, Ч. 7-8, С. 178.

14 Там само, Ч. 11-12. С. 291292.

${ }^{15}$ Одесские новости. 1918. 21 января.
Полковник армії УНР, службовець штабу Одеської військової округи у січні 1918 р. М. Омелянович-Павленко згадував, що вже у дні більшовицького повстання поширювалася інформація «про страхіття, що робили матроси над Українцями. Корабельна «топка» (піч) вже не могла виконувати своїх обов'язків «автодафе» й «контр-революціонерам» просто прив'язували каменюки до ніг i кидали у море». У середовищі солдат ходили плітки, що його теж упіймали й кинули у «топку», а крейсер став осередком ЧК ${ }^{11}$.

Ще більш яскравими стали спомини іншого учасника подій прапорщика 1-го Гайдамацького запасного куреня Г. Гришка, котрий згадував про своє затримання і відвідини корабля зі зрозумілою емоційністю: «Ось так я опинився на тому знаменитому (виділення наше - T. В.) «Алмазі». До того я ще про нього нічого не чув. Знав лише, що це була невеличка яхта 3 двома невеликого калібру гарматами далекого бою. Коли підійшли ми ближче, я побачив тут таке, чого на все життя не забуду. На чердаку, опершися спинами на залізний борт, який механічно відкривався, лицем до середини стояло чоловік 8-10, цілковито голі. Були пов'язані по два до себе, а далі поміж двома до ніг було прив'язане кожній парі велике куляте залізо. Ці люди стояли як тіні й слухали як якийсь матрос $<\ldots>$ читав їм рішення найвищого воєнного революційного суду - смертний вирок за участь в організації «братовбивчої війни». При словах: «ви всі заслужили смертну кару й вас належить розстріляти, але на таких злочинців шкода витрачати патронів, а тому будете потоплені» - відчинилися борти й тільки було чути «слава» та плеск хвиль Чорного моря. Тоді один $<\ldots>>$ обернувся до мене: «а правда красиво бореться совєтская власть з буржуазією?»» ${ }^{12}$. До загиблих на «Алмазі» він записав унтер-офіцера 1-го Одеського авіаполку, голову Одеської української військової ради (далі ОУВР), службовця ОВО М. Іванівського, котрого за словами Г. Гришка спалили живцем у корабельній пічці ${ }^{13}$.

Далі останній розповідав, що в камері «Алмаза» разом $з$ ним залишалося ще 16 затриманих. Їх охопив стан відчаю і лише співом вони намагалися заглушити відчуття трагічної перспективи. Самого Г. Гришка за декілька годин врятував один з невідомих червоногвардійців або матросів, який ініціював конвоювання заарештованого на суд, але під час транспортування розв'язав йому руки й наказав втікати. Той побіг до оперативного штабу українських військ і розповів там про побачене. За його словами решта бранців начебто таким самим шляхом зуміли уникнути смерті, хоча у цій частині споминів Г. Гришко назвав цифру 18 осіб ${ }^{14}$.

Альтернативну кількість в'язнів «Алмаза» станом на кінець січня подавали «Одесские новости». За їхніми даними на крейсері перебувало 34 особи, з них 26 звільнили, а ще 8 «забрали червоногвардійці». У цьому ж дописі йшлося про звільнення під розписку утримуваних на «Синопі» офіцерів, 3-поміж них командира української бригади полковника М. Мазуренка. Вони взяли на себе зобов'язання не виступати проти «радянської влади» і за першої вимоги з'являться до революційного трибуналу ${ }^{15}$.

Доповнював загальне тло подій інший одеський часопис, на шпальтах якого розповідалося, що у перші дні після встановлення 
Воронцовський палац. 1927 рік

${ }^{16}$ Найімовірніше Микола Холодовський.

${ }^{17}$ Родная страна. 1918. 20 января.

18 Там же.

${ }^{19}$ Вільне життя. 1918. 13 квітня.

${ }^{20}$ Файтельберг-Бланк, В., Савченко, В. Указ. соч. С. 74.

${ }^{21}$ Одесские новости. 1918. 15 февраля.

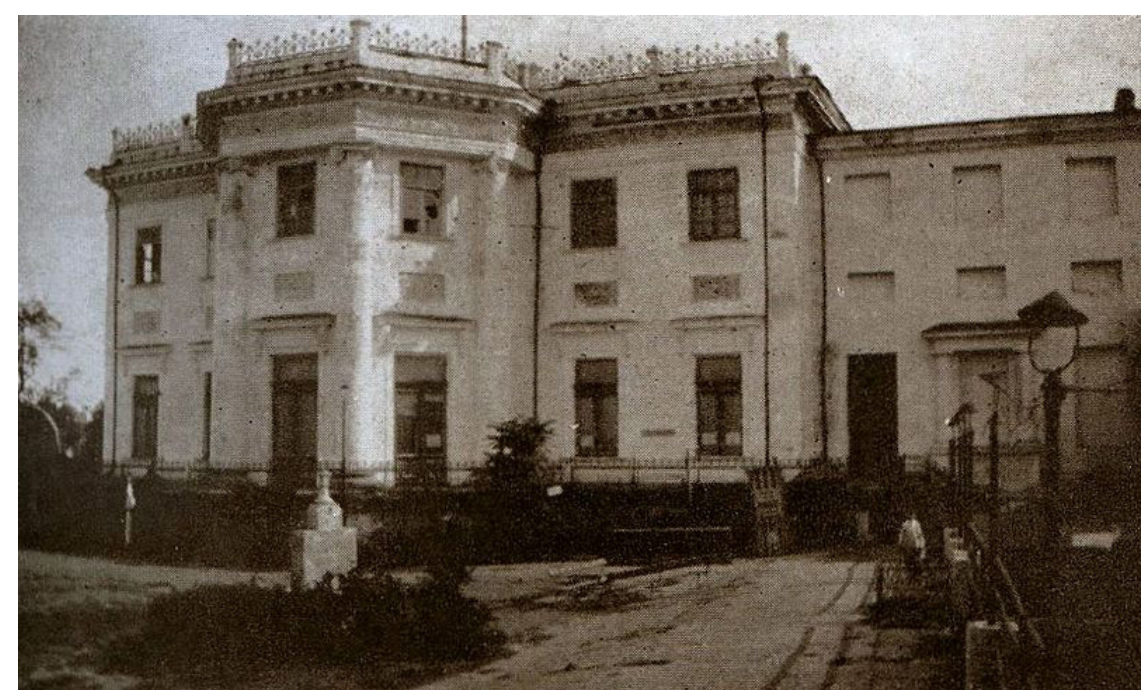

в Одесі більшовицької влади у різних частинах міста відбулися арешти офіцерів та юнкерів українських військових частин. Серед інших називалося прізвище ген. Холодовського ${ }^{16}$. Затримання проходили здебільшого в готелях і на приватних квартирах, а кількість підозрюваних виявилася настільки великою, що їх не могли помістити в одне приміщення, тому розділили на три групи. Одна опинилася в штабі Червоної гвардії, інша - в Румчероді, а решта на військових кораблях. Також «Родная страна» повідомляла, що тоді ж безперервно засідав революційний трибунал (вул. Дерибасівська, 2), розглядаючи справи затриманих. Декого відразу відпускали, комусь щастило менше, бо їх затримували до повного з'ясування провини. При цьому представники трибуналу на запитання цивільного населення щодо долі ув'язнених давали обіцянки не застосовувати смертну кару, бо «у вільній Росії вона скасована», не допускати самосуду і «диких ексцесів до заарештованих» ${ }^{17}$.

Втім потенційними жертвами репресій ставали не лише військові, але й інші категорії осіб. Так, загроза арешту нависла над відомим у місті актором В. Вронським ${ }^{18}$, або над пересічними мешканцями, як наприклад, О. Щербак, котра post factum дякувала добродіям С. Зінченку, М. Григоровичу (мабуть обоє колишні редактори газети «Солдатська думка»/«Рідний курінь» - Т. В.) і Тимошенку за свій порятунок 3 «Алмаза» ${ }^{19}$.

Попри інформацію щодо звільнення частини затриманих Одесою вперто поширювалися чутки про розправи на крейсері. Занепокоєння долею ув'язнених виявилося настільки помітним, що ситуацію намагалася взяти під свій контроль міська дума. Вона створила спеціальну делегацію для вияснення стану речей. До іiі складу увійшли члени міської управи М. Пташицький і П. Шумілов, гласні В. Коробков й М. Цвіллінг. 10 лютого (28 січня) за присутності представника ревтрибуналу (голова анархіст В. Білий ${ }^{20}$ ) їм дозволили оглянути «Алмаз», де утримувалися комендант залізничної станції Одеса-Головна підполковник Л. Жуковський (ревтрибунал незабаром віддав його на поруки за проханням польського комісара міста, який посилався на прохання польської громади Одеси ${ }^{21}$ ) і телеграфний чиновник Бєлов. На запитання про факти самосуду голова Румчероду і Одеської ради народних 
22 Там же. 30 января.

23 Держархів Одеської області, Ф. П-13, Оп. 3, Спр. 8, Арк. 4-5.

${ }^{24}$ Шишко, О. Г. (2011). «Одеська радянська республіка»: політика терору. У Інтелігенція $i$ влада. Громадсько-політичний науковий збірник. Серія: Icторія. Вип. 22. Одеса: Астропринт, С. 174-176.

25 Держархів Одеської області, Ф. 4, Оп. 4, Спр. 135 , Арк. 59 зв., 60 зв.

${ }^{26}$ Там само, Ф. П-13, Оп. 3, Спр. 8, Арк. 1-2; Там само, Спр. 7, Арк. 29.

${ }^{27}$ Шишко, О. Г. (2011). «Одеська радянська республіка»: політика терору. У Інтелігенція $i$ влада. Громадсько-політичний науковий збірник. Серія: Icторія. Вип. 22. Одеса: Астропринт, С. 174-175.

${ }^{28}$ ЦДАВО України, Ф. 1705 , Оп. 1, Спр. 6, Арк. 28.

${ }^{29}$ Держархів Одеської області, Ф. 4, Оп. 4, Спр. 135, Арк. 61.

${ }^{30}$ Одесские новости. 1918. 15 февраля. комісарів В. Юдовський відповів, що йому відомі лише три такі факти, маючи на увазі позбавлення життя службовців поліційних структур $^{22}$. Про них мабуть розповідав і М. Аркушенко, запевняючи, що вбитими були чиновники й офіцери царської «охранки» та розшукового відділу Бульварної дільниці ${ }^{23}$.

Якщо зважити на спогади М. Омеляновича-Павленка і Г. Гришка, то очевидно, що думська делегація не мала жодних шансів виявити сліди страти людей, оскільки використовувався специфічний метод позбавлення їх життя. А відповідна документація не стала предметом дослідження з боку комісії. Зрештою міська дума призначила слухання за результатами роботи делегації, які відбулися 14 (1) лютого 1918 р., позаяк гласні продовжували мислити категоріями революційної демократії, яка передбачала наявність принципу презумпції невинуватості для прийняття відповідних рішень. Роботу делегації першим проаналізував О. Шишко ${ }^{24}$, ми розширимо дослідницьке поле за рахунок залучення додаткових джерел.

Отже, на засіданні думи від імені делегації виступив М. Цвіллінг, який сказав, що їхня комісія відвідала чотири місця, де перебували міські в’язні. Маршрут інспекторів прокладався від в'язниці до «Алмаза», далі на «Синоп» і завершувався у приміщенні Червоної гвардії (вул. Торгова, 4). Прикметно, що значну частину виступу він присвятив оцінці нестерпного санітарного стану тюрми, хоча присутніх також цікавили результати перевірки «Алмаза», чутки навколо якого залишалися найжахливішими. Пояснення доповідача супроводжувалися значною долею скептицизму щодо можливості здійснити повноцінний аналіз ситуації. М. Цвіллінг стверджував, що на крейсері їх зустріли стримано, а за аналізом списків затриманих він дійшов висновку про загибель українського військового Іваницького, сина військового комісара уряду УНР В. Поплавка і члена УСДРП, офіцера Гайдамацького куреня Омеляна Туза. При цьому наполягав, що обставини їхнього вбивства не встановлені, тому вони могли бути позбавлені життя не на крейсері, а по дорозі до нього. Доповідач побічно підтвердив тезу про імідж «Алмаза» $\mathrm{i}$ «Синопа» як ефективний метод впливу на незгідних ${ }^{25}$, що не приховувалося й самими організаторами та свідками репресій ${ }^{26}$. Відзначимо, що у праці О. Шишка йдеться про Г. Іваницького ${ }^{27}$, але на нашу думку це військовослужбовець 40-го піхотного запасного полку, з 28 (15) листопада 1917 р. член виконавчого комітету ОУВР Костянтин Іваницький ${ }^{28}$.

Запропонований шаблон висновків викликав незадоволення частини гласних, від яких вступив у полеміку С. Шапіро. Він закинув М. Цвіллінгу, що комісія фактично не виконала одне 3 найважливіших завдань інспекції - не виявила факти самосуду на військових кораблях ${ }^{29}$, бо точаться розмови про таємничі зникнення людей та викинуті в море трупи. Відтак поки на ці питання громадськість не отримає відповіді, то не заспокоїться ${ }^{30}$. Не володіючи доказовою базою М. Цвіллінг парирував слова опонента припущенням про ліквідацію більшості затриманих більшовиками й анархістами, оскільки на «Алмазі» вони побачили лише двох 
31 Держархів Одеської області, Ф. 4, Оп. 4, Спр. 135, Арк. 61.

32 Там само, арк. 61, 61 зв.

${ }^{33}$ Коновалов, В. Г. (1989). Подвиг «Алмаза»: документальная повесть. Одеса: Маяк, C. 168 .

${ }^{34}$ Файтельберг-Бланк, В., Савченко, В. Указ. соч. С. 76.

${ }^{35}$ Родная страна. 1918. 20 января. в'язнів, а на «Синопі» одного. Отже, на його думку, решта відійшли у засвіти ${ }^{31}$.

У ході жвавого обговорення слово також взяв Д. Іваненко, який повідомив присутнім про свої випадкові перемовини 3 напівп'яним «головою «Алмаза»», який відверто зізнавався, що підписав 4 смертних вироки й запрошував через годину бути присутнім на розстрілі. Також гласний переповів слова інших людей про спалення живцем в пічці крейсера тих осіб, котрі проявляли потяг до продовження боротьби проти нової влади. Слова останнього змусили М. Цвіллінга наполягати на перевірці таких фактів, бо вони могли бути звичайною брехнею ${ }^{32}$. Здається остання думка гласного базувалася радше на емоційному неприйняті самої можливості використання такого методу знищення людей, тому він й висловився у відповідному річищі.

Апеляція до громадськості з боку С. Шапіро не стала звичайною мовною конструкцією, позаяк подекуди у публічному просторі з'являлися різкі оцінки діям більшовицької влади. Чи не найбільш критичну позицію зайняла редакція газети «Южный рабочий $\rangle^{33}$, а у нарисах одеських авторів наводиться пізніший приклад рефлексії священика О. Введенського на моральні й політичні аспекти життя Одеси після встановлення нової влади, висловлені на шпальтах газети «Родная страна»: «Усі мовчазно підпорядкувалися більшовикам < ..> пристосовуючись до їхньої мови, моралі, понять... Власне іншого виходу й не було. За найменший спротив відразу відправляли на «Алмаз», де без будь-якого суду і слідства розстрілювали, топили або спалювали в пічках. Звідти, кажуть, ніхто не повернеться» ${ }^{34}$.

Преса дійсно дозволяє суттєво розширити наратив про початок розгортання «червоного» терору. Так, «Родная страна» звернула увагу на обставини затримання молодшого Поплавка. Вона писала, що у готелі «Петроградський» (розташовувався на Приморському бульварi, 8 - T. В.) було затримано елегантного молодого чоловіка, озброєного гранатою. Заарештований спочатку приховував своє прізвище, але потім заявив, що він $є$ сином українського комісара В. Поплавка. Його спочатку відправили до приміщення військової секції Румчероду, а далі на «Алмаз». Посилаючись на дані часопису «Голос революции», редколегія розповідала, що $\epsilon$ підстави вважати начебто ув'язнений очолював гайдамацькі підрозділи ${ }^{35}$, що й до сьогодні не отримало підтвердження в джерелах та науковій літературі.

Грізна тінь «Алмаза» супроводжувала життя Одеси і у наступні тижні, нависаючи майже неминучою загрозою арешту за найменшої підозри у «контрреволюційності». Яскравим прикладом сказаного стала зустріч Головнокомандувача збройними силами Одеської радянської республіки підполковника М. Муравйова 3 представниками міського самоврядування, банкірами, підприємцями, котра пройшла 19 лютого 1918 р. У ході дискусії з заступником міського голови Б. Фрідманом, який насмілився вступити в полеміку з новою владою, прибулий з Києва російський командир завершив бесіду фразою: «Взяти його! На Алмаз!». Щоправда його відправили не в порт, а на залізничний вокзал і незабаром 
${ }^{36}$ Шишко, О. Г. (2011). «Одеська радянська республіка»: політика терору. У Інтелігенція $i$ влада. Громадсько-політичний науковий збірник. Серія: Icторія. Вип. 22. Одеса: Астропринт, С. 174-176.

${ }^{37}$ Одесские новости. 1918.

21 февраля.

${ }^{38}$ Коновалов, В. Г. (1989). Подвиг «Алмаза»: документальная повесть. Одеса: Маяк, C. 167.

${ }^{39}$ Одесские новости. 1918. 3 марта.

40 Держархів Одеської області, Ф. 4, Оп. 4, Спр. 135, Арк. 104.

${ }^{41}$ Там само, Арк 108 зв.

${ }^{42}$ Там само, Арк. 110-111. звільнили ${ }^{36}$. Саме на крейсері М. Муравйов провів зібрання з підлеглими на якому віддав наказ почати обшуки й арешти офіцерів, що негайно втілювався в життя ${ }^{37}$.

За словами В. Коновалова корабельний комітет «Алмаза» ще на початку лютого звернувся до Румчероду з пропозицією ізолювати «найбільш реакційно налаштованих буржуазних діячів», але прийняття такого рішення затрималося. Лише проти ночі 2 березня 1918 р. за постановою Румчероду були заарештовані 69 осіб, що викликало відверте обурення громадськості, тому вже 4 березня їх звільнили ${ }^{38}$.

Негативний образ бойового корабля настільки міцно закріпився у свідомості мешканців міста, що на початку весни 1918 р. у місцевій пресі було опубліковано «Заяву команди “Алмаза"». У ній йшлося, що усі чутки про перетворення корабля в катівню неправдиві, на борту не пролито жодної краплини крові, не віднято бодай одного життя. Існування пліток «алмазівці» трактували виходячи $з$ їхньої подвійної природи. На їхню думку такі поголоски розповсюджували базіки, а також свідомі провокатори, дії яких були спрямовані на формування відповідного іміджу пароплава. Автори відозви запрошували усіх бажаючих відвідати судно, щоб переконатися у неправдивості отримуваної інформації ${ }^{39}$. Втім у такий спосіб використовувався прийом, котрий вже спрацював у випадку з делегацією міської думи, адже неможливо відшукати сліди злочинів, якщо їх встигли ретельно прибрати.

Необхідність рятувати вкрай зіпсоване реноме судна підкреслювалася ще одним епізодом, про який згадав під час засідання думи 8 березня 1918 р. міський голова В. Богуцький. Характеризуючи настрої службовців торгівельного флоту він стверджував, що вони рішуче налаштовані самостійно покарати насильників і грабіжників, «розправитися навіть 3 «Алмазом» i «Синопом» та іншими», бо їхні дії становлять серйозну загрозу «інтересам фабричного населення» ${ }^{40}$. Щоправда до реалізації озвучених силових намірів справа не дійшла, бо за тиждень більшовики та iï репресивні органи відступили з Одеси під тиском наступаючих німецьких та австрійських військ. Втім матроси встигли заарештувати й відправити на «Алмаз» гласного М. Циварьова, який був включений до складу делегації міського самоврядування для переговорів з союзницьким командуванням щодо умов перебування армій країн Четверного союзу в місті. Інші гласні-переговірники уникнули затримання, встигнувши заховатися ${ }^{41}$.

Натомість інша частина гласних, котрих неформально очолював М. Цвіллінг, розпочали переговори з Раднаркомом Одеської радянської республіки, радою матроських депутатів, Румчеродом i командою «Алмаза» на предмет уникнення бойових дій з військами Німецької та Австро-Угорської імперій, насамперед щоб не використовувався військово-морський флот ${ }^{42}$, гармати якого могли зруйнувати Одесу.

Разом зі вступом в місто 14 березня підрозділів союзників й відновленням влади УНР у регіоні місцеві інституції повернулися до ідеї повноцінного встановлення усіх обставин, пов'язаних 3 можливими розправами на крейсері, який за словами В. Конова- 
${ }^{43}$ Коновалов, В. Г. (1989). Подвиг «Алмаза»: документальная повесть. Одеса: Маяк, C. $189-190$

${ }^{44}$ Ачканов, Г. (1927). От Февраля к Октябрю. У Октябрь на Одешине. Сб. статей и воспоминаний к 10-летию Октября. Одеса, С. 34; Держархів Одеської області, Ф. П-13, Оп. 2, Спр. 118, Арк. 39.

45 Держархів Одеської області, Ф. П-13, Оп. 3, Спр. 330, Арк. 7.

${ }^{46}$ Одесские новости. 1918. 15 марта.

${ }^{47}$ Там же. 16 марта.

48 Южная мысль. 1918.

23 марта.

${ }^{49}$ Одесские новости. 1918. 17 марта.

${ }^{50}$ Родная страна. 1918. 27 марта; Ведомости Одесского градоначальства. 1918. 28 марта. лова залишив одеський рейд 15 березня 1918 р. Він також зауважив, що «буржуазна і погоджувальна преса» писала про багато десятків білогвардійських офіцерів й представників буржуазії, які перебувають на морському дні, але відповідні компетентні органи не знайшли доказів вбивств на «Алмазі» ${ }^{43}$. Хоча навіть у спогадах більшовиків не приховувалося, що там декого з буржуазії і офіцерів «списували в расход» ${ }^{44}$. Комісар казначейства Одеси Г. Фокєєв також додавав, що він перед вступом до міста союзницьких армій переправив на «Алмаз» і «Синоп» 3,5 млн. карб. для вивезення в Севастополь ${ }^{45}$.

Винесемо за дужки характерний для радянської історіографії дискурс про епоху в контексті протистояння «революціонерів контрреволюціонерів» або «червоних - білих», адже у січні 1918 p. контрагентом більшовиків були не білогвардійські офіцери, а військо УНР. Зосередимося на реконструкції подій, пов’язаних 3 пошуком зниклих осіб навесні 1918 р.

Згідно інформації «Одесских новостей» за розпорядженням міського самоврядування 14 березня до Севастополя була відправлена радіотелеграма з проханням вжити заходи для звільнення 63 осіб, у тому числі відомих державних діячів Румунського королівства, заарештованих матросами і вивезених з Одеси на «Алмазі», «Синопі» та інших плавзасобах ${ }^{46}$.

Але не менша увага приділялася ідентифікації місця загибелі ув’язнених та їхніх імен. 15 березня на засіданні Одеської української міської ради (далі ОУМР), яка на перших порах виконувала функції регіонального представника уряду УНР, один з солдат, котрий пробув під вартою на «Синопі» декілька днів, просив спорядити водолазів для підняття 3 морського дна тіл загиблих. Також він розповів деталі вбивства К. Іваницького, якого утримували на «Синопі», а життя позбавив матрос пострілом упритул ${ }^{47}$. «Южная мысль» навіть наводила прізвище можливого вбивці українського офіцера. Ним міг бути Гриценко, який чи не найактивніше ініціював розправи на «Синопі». Ця ж газета детально переповідала обставини самосуду над секретарем Гайдамацького куреня О. Тузом, якого, за даними іiі інформаторів, вбили на причалі між «Синопом» $\mathrm{i}$ «Ростиславом» ${ }^{48}$. Панахида по К. Іваницькому, О. Тузу та іншими особами мала відбутися вже 17 березня ${ }^{49}$.

Після передачі повноважень від ОУМР до Головного крайового комісаріату Херсонської, Таврійської і Катеринославської губерній на чолі з С. Комірним, який прибув до Одеси 18 березня 1918 р., з'явився наказ за підписом нового керівника південного регіону, котрий доручав усім урядовим закладам і посадовим особам військового, військово-морського й цивільного відомств, а також громадським організаціям надавати повне сприяння комісії по розслідуванню злодіянь здійснених в Одесі з 28 (15) січня по 15 березня 1918 р., яку очолював Трегубов ${ }^{50}$.

У пресі повідомлялося, що 16 березня на загальному зібранні усього складу військово-морського суду (вул. Дерибасівська, 2), до якого входили А. Шаміє (голова), Н. Кірпотін (військово-морський суддя), А. Александров (прокурор), Г. Ненароков (помічник прокурора), Н. Павлович (слідчий), було прийнято постанову від- 


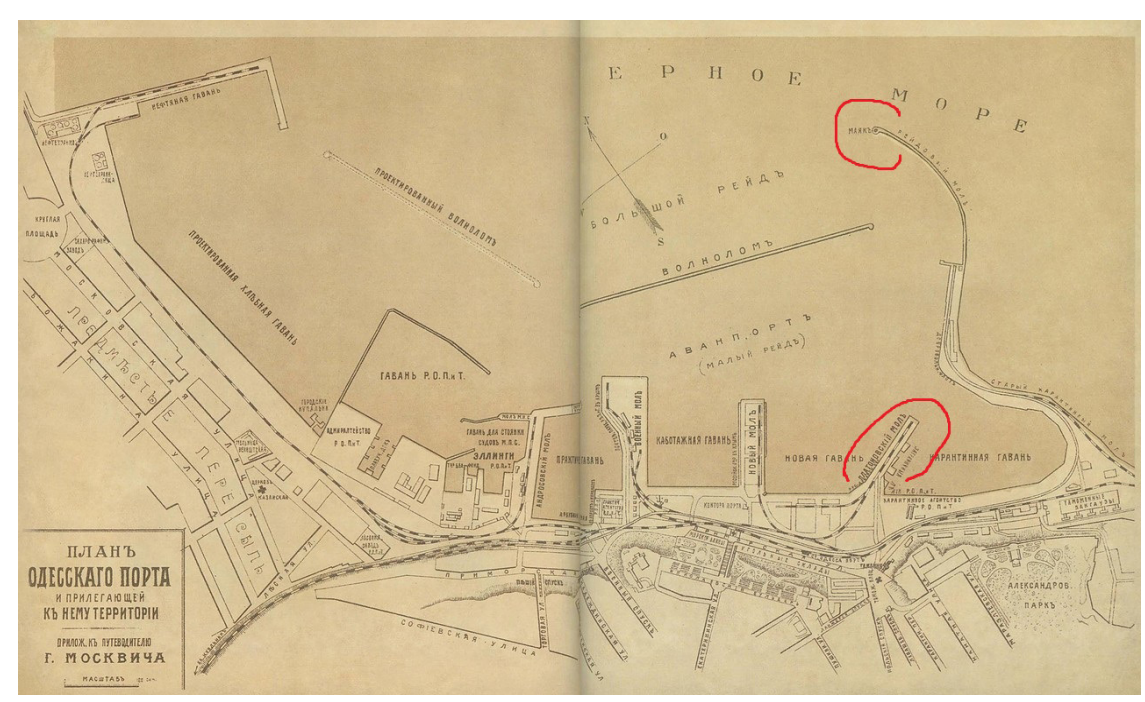

${ }^{51}$ Одесские новости. 1918. 17 марта.

52 Южная мысль. 1918.

20 марта.

${ }^{53}$ Одесские новости. 1918. 17 марта.

54 Там же. 19 марта, 20 марта, 21 марта.

${ }_{55}$ Родная страна. 1918.

21 марта. новити його діяльність ${ }^{51}$. «Южная мысль» додавала до переліку членів військово-морського суду слідчих Черняка і Немітця, секретаря Н. Клименка і адвоката Н. Дмітрієва ${ }^{52}$.

Прокурор суду А. Александров першочергово запропонував Н. Павловичу відкрити провадження щодо вбивства матросами низки офіцерів на «Синопі» та «Алмазі». Слідство розпочалося того ж дня. Резонансна справа не могла обійтися без пильного контролю громадськості, тому до надзвичайної слідчої комісії по розслідуванню вбивств, грабунків, насильства і експропріацій мали увійти також представники міського самоврядування, громадських організацій і присяжної адвокатури ${ }^{53}$.

Слідчі дії головним чином зосередилися навколо пошуку двох типів доказів - свідчень очевидців та обстеження потенційного місця злочинів - адже документальна база була відсутня через позасудові рішення більшовицьких органів влади або завдяки спонтанним діям матросів, червоногвардійців чи інших осіб, які позбавляли життя затриманих на власний розсуд. Оскільки за розповідями ув'язнених вбивали здебільшого трьома способами живцем спалювали в пічці корабля, скидали з прикріпленим до ніг вантажем на морське дно або у такий спосіб позбавлялися тіл розстріляних - то необхідно було дослідити місця стоянки суден «Алмаза», «Синопа» $\mathrm{i}$ «Ростислава» й поблизу Воронцовського маяка зі сподіванням знайти трупи закатованих. Пошуки під наглядом Н. Павловича тривали 19-21 березня 1918 р., але перші занурення пірнальників дали негативні результати. Вони знайшли лише багато ящиків зі спиртним, вкраденими в портових пакгаузах припасами, набоями, кулеметні стрічки і трьохдюймову гармату ${ }^{54}$.

Такий хід подій змусив прокурора розтлумачити позицію слідства щодо амбівалентних перспектив розшуку тіл й можливого призупинення робіт після первинного обстеження окреслених локацій. Він наголосив на тому, що мало місце припущення про маскування вбивцями своїх дій шляхом вивезення жертв у відкрите море, а для таких пошуків не вистачало ні технічних ресурсів, ні людей ${ }^{55}$.

Прикметно, що В. Коновалов, загалом точно передавши газетну інформацію, уникнув згадки про знайдене спиртне і погра- 
${ }^{56}$ Коновалов, В. Г. (1989). Подвиг «Алмаза»: документальная повесть. Одеса: Маяк, C. 190 .

${ }^{57}$ Одесские новости. 1918. 22 марта.

${ }^{58}$ Вільне життя. 1918. 12 квітня; Одесские новости. 1918. 13 апреля.

${ }^{59}$ Одесские новости. 1918. 22 марта.

${ }^{60}$ Там же. 23 марта, 24 марта. бовані харчові запаси. Так само вибірково він доносив читачеві наступні повідомлення, виділивши ті фрагменти, які допомагали конструювати героїчний образ «Алмаза», запозичивши тези про виконання робіт 3 «особливою інтенсивністю» і те, що на крейсері «вбивств здійснено не було». При цьому не зауважив, що трупи вбитих на місці стоянок «Ростислава» і «Синопа» водолази відшукали ${ }^{56}$.

Натомість у пресі подавався ширший контекст результатів пошукової операції. «Одесские новости» запевняли містян, що за отриманими даними число жертв не таке велике як передбачалося, загалом знайдено 12 тіл. Значна частина утоплених знаходилася в тих точках, де стояли «Ростислав» і «Синоп». Трьох мерців знайшли на місці перебування транспорту «Дунай», на дні лівої сторони Платонівського молу. Припускали, що саме тут були кинуті у воду тіла розстріляних К. Іваницького й О. Туза ${ }^{57}$.

Згодом газета «Вільне життя» опублікувала статтю «Суд над Іваницьким», розповівши окремі деталі трагедії військового, котрі передрукували «Одесские новости». За їхніми даними його заарештували і вивезли на «Синоп», де кинули у вугільну яму. За два дні член ревкому з «Алмаза» зробив запит голові виконкому ради матроських і офіцерських депутатів Одеського порту Суковському щодо подальших перспектив К. Іваницького, «який здається є родичем буржуя контрреволюціонера Поплавка». Відповідь несла у собі категоричний імператив «Що ви на нього дивитеся, негайно розстріляйте!». Подальша розповідь стосувалася останніх хвилин життя затриманого. К. Іваницького витягнули з ями й запитали: «Хочеш ще пожити?». Думаючи, що його хочуть звільнити він відповів: «А хто не хоче жити!». Далі він почув: «Так ось тобі живи!» й отримав постріл з револьвера ${ }^{58}$.

Чимало газетної площі виділила редколегія «Одесских новостей» для розповіді про спроби ідентифікації лікаря В. Соколова. Спочатку повідомлялося, що його тіло вочевидь перебуває на місці стоянки «Синопа», поряд 3 трупами генерала Л. Томашевича, Пономарьова, чиновника санітарного портового управління Благодельського та інших. А далі дописувач переповів, що 21 березня в морг привезли тіло, у якому упізнали В. Соколова, якого начебто пограбували і кинули в море роздягнутим. Він був без носа й вух, які мабуть з'їли риби, туловище набухло та розкладалося, до правої ноги був прив'язаний важкий камінь, до лівої залізяка ${ }^{59}$.

За словами журналістів слідство виявило, що усіх трьох вбили пострілами у переносицю біля Платонівського молу на одному з транспортних суден, котрий стояв поблизу «Синопа», а потім скинули у море поблизу Воронцовського маяка. 23 березня в цей район на човні виїхав поручник А. Мірасхеджи для точної локалізації місця, куди кинули трупи. Трагічності смерті додавали обставини ув'язнення, адже за оприлюдненими у газеті даними неозначені особи насправді шукали портового лікаря Таранова задля помсти. Припускали що той ховається у помешканні В. Соколова, але не знайшли його там. Тому господаря квартири і його випадкового гостя Благодельського взяли у заручники, а Л. Томашевича випадково затримали на вулиці ${ }^{60}$. 
61 Южная мысль. 1918. 23 марта.

${ }^{62}$ Вільне життя. 1918. 31 березня.

${ }^{63}$ Мисечко, А. І. Вказ. праця. C. 194.

${ }^{64}$ Одесские новости. 1918. 22 марта, 24 марта, 30 марта.

${ }^{65}$ Южная мысль. 1918. 30 марта.

${ }^{66}$ Вільне життя. 1918.

31 березня; Одесские новости. 1918. 30 марта.

${ }^{67}$ Держархів Одеської області, Ф. 4, Оп. 4, Спр. 135, Арк. 163 зв.

${ }^{68}$ Мабуть йдеться про генерал-лейтенанта Євгена Леонтовича, який у першій половині 1918 р. очолював Одеський вербувальний центр Добровольчої армії.
Схожий сюжет пропонувала читачам редколегія «Южной мысли», яка повідомляла, що Л. Томашевича роздягнули до білизни, в інших забрали цінні речі, після чого до кожного $з$ них підходив «глава шайки» і стріляв у лоба. Далі вбивці прив'язали до ніг жертв вантаж й скинули в море за декілька десятків кроків від місця страти ${ }^{61}$, що відрізнялося від визначеної в «Одесских новостях» точки приховування трупів.

Матеріали 3 описом закатованих пропонувалися читачам й надалі задля полегшення процедури упізнання. Зокрема розповідалося, що неподалік від місця стоянки «Дунаю» 20 березня витягнули з води труп людини, одягнутої в шинель сірого сукна, 3 мідними гудзиками, гімнастерку захисного кольору, чорні рейтузи, на білизні читалася мітка «Е. С.», а на носовичку літера «С». Шию жертви прикривав старий шалик, під ним містився золотий хрестик і медальйон на ланцюжку. Детальний опис допоміг встановити, що йдеться про офіцера 1-го Гайдамацького куреня армії УНР Свгена (за іншими даними Остапа ${ }^{62}$ ) Сиса. Слідчі дії встановили, що його заарештували на квартирі через день-два після більшовицького повстання і відвели на одне з суден. За декілька годин червоногвардійці і матроси повернулися до помешкання й заявили квартирній господині, що С. Сис вбитий. Журналісти «Одесских новостей» подавали різну інформацію щодо результатів судово-медичної експертизи, про що частково писав А. Мисечко ${ }^{63}$. За одними даними патологоанатоми виявили у тілі 6 вогнепальних ран, а за іншими його вбили двома пострілами в район серця і голову. Перед стратою військового катували, бо була цілковито знищена грудна клітка і спотворено тіло, яке потім скинули в море, прив'язавши до ніг камінь вагою близько 13,5 кг ${ }^{64}$.

Похорон хорунжого С. Сиса відбувся 30 березня 1918 р. У ньому мали взяти участь практично усі українські громадські та учнівські організації міста, котрі колективно планували вирушити на поховальну процесію з приміщення «Української хати» (вул. Князівська, 30) ${ }^{65}$. До Собору зійшлася велика кількість людей, а австрійське командування надіслало свій почесний караул. На Другому Християнському цвинтарі Одеси о. А. Гриневич виголосив промову. Потім виступили побратими покійного Матяшин i С. Максимчук, закінчилася церемонія виконанням «Ще не вмерла Україна» ${ }^{66}$.

Кривавий шлейф за кільватером «Алмаза» тягнувся ще протягом тривалого часу. Так, гласний С. Штерн, обговорюючи на засіданні міської думи 9 квітня 1918 р. поточні політичні справи, зокрема критикуючи наказ Одеського повітового коменданта про обов'язковий виїзд за межі УНР офіцерів, котрі не $\epsilon$ іï громадянами, згадав нещодавнє минуле такими словами: «<... Більшовики громадян вбивали, катували, саджали на «Алмаз» і під «Алмаз» $<\ldots>$ Тому Україна має бути вдячна цим офіцерам за те, що вони не перейшли до більшовиків ${ }^{67}$. За тиждень представник товариства офіцерів Одеси ген. Леонтович ${ }^{68}$, обговорюючи цей наказ, теж апелював до періоду «червоного» терору, розповідаючи про «Муравйовські дні», коли за його словами безслідно пропали 4200 
69 Держархів Одеської області Ф. 4, Оп. 4, Спр. 135, Арк. 30.

${ }^{70}$ Омелянович-Павленко, М. Вказ. праця, С. 56.

${ }^{71}$ Пилишенко, В. Вказ. праця, C. 27.

72 Там само.

${ }^{73}$ Коновалов, В. Г. Вказ.праця, C. 215-216, 242 .

${ }^{74}$ Шишко, О. Г. (2011). «Одеська радянська республіка»: політика терору. У Інтелігенція $i$ влада. Громадсько-політичний науковий збірник. Серія: Icторія. Вип. 22. Одеса: Астропринт, С. 175.

75 Южная мысль. 1918.

20 марта.

${ }^{76}$ Одесские новости. 1918. 13 апреля. офіцерів, у тому числі їх топили в морі й спалювали у корабельній пічці ${ }^{69}$.

У своїх спогадах М. Омелянович-Павленко, згадуючи описувані події, занотував: «<..> Пізніше, коли Німці увійшли до міста, я чув, що водолази не могли знести тих картин, які відкривала перед ними морська глибінь. Люде, як казкові істоти, творили на дні легіон мертвих» ${ }^{70}$.

Детальніше пошуки загиблих описував екс-очільник Одеської української морської ради В. Пилишенко, цитату якого подаємо 3 адаптацією: «У лютому 1918 р. усі одеські в’язниці були переповнені «контрреволюціонерами», які не встигли утекти з міста. Серед арештованих були вчені, музики, артисти, письменники. За що їх посадили, того ніхто не знав, навіть самі чекісти. В Одесі слова «взяти його на Алмаз» ще довший час після тієї трагедії були на устах у мешканців < ..> Дружини загиблих звернулися до місцевих пірнальників 3 проханням підняти трупи їхніх чоловіків із дна моря, щоб можна було їх поховати. Вони пообіцяли водолазам гідну платню за роботу, але майже ніхто з них не зголосився виконати таку функцію. І лише у середині квітня 1918 р. згорьовані родичі знайшли сміливця. Ним став досвідчений фахівець підводної справи Сергій Коваленко <..> Район занурювання показали очевидці, після чого пірнальник $<\ldots>$ опустився під воду. Більше півгодини на катері була тиша в очікуванні сигналу від С. Коваленка. Після різких безперервних сигналів його підняли i, знявши скафандр, завмерли від жаху. Він посивів, виглядав дуже наляканим і не міг промовити жодного слова. Декілька днів пробув С. Коваленко у психіатричній лікарні, але й після цього він не зміг розповісти про побачене на дні моря $<\ldots>$. $^{71}$.

Закінчуючи свою трагічну оповідь В. Пилишенко стверджував: «<..> за півроку у свідомості хворого наступив перелом і він заговорив < ..> Оповідь колишнього циркового атлета змалювала жахливу картину. Після спокійного на початку морської прогулянки обстеження дна його ліхтарик витягнув 3 темряви значну кількість людей, котрі стояли притримувані за ноги тягарем й погойдувалися. Очі у багатьох були відкриті, в декого обличчя та руки вже були погризені рибами. Сам С. Коваленко опинився у гущі підводного кладовища, а мерці наче штовхали його руками» ${ }^{72}$.

Стислу версію сюжету, який глибоко засів у пам'яті М. Омеляновича-Павленка і В. Пилишенка, знаходимо й у праці В. Коновалова, який зазначав, що їі друкувала місцева преса ${ }^{73}$. А О. Шишко влучно підмітив схожість одеської розповіді з аналогічною ялтинською легендою ${ }^{74}$. Описані в споминах фрагменти значною мірою базувалися на чутках, які вирували в місті. Вони змусили А. Александрова виступити з заявою, що за результатами занурень водолазів протягом 19-20 березня не знайдено декілька сотень тіл, про що говорили одесити, й ніхто з чотирьох залучених до робіт пірнальників не збожеволів, а площа обстеження настільки велика, що слідча комісія запросила допомоги підводників $3 \mathrm{Xерсона}^{75}$. Втім в одному з пізніших дописів певну долю ймовірності божевілля побічно підтверджували «Одесские новости», переповідаючи слова відповідальних осіб, котрі вказували на небажаність користуватися послугами водолазів «зі зрозумілих причин» ${ }^{76}$. 
Нам не вдалося відшукати документів слідчої комісії за допомогою яких можна було б дати максимально точну відповідь на три ключові питання - про дату завершення пошукових робіт, кількість жертв та їхні імена, тому наразі оперуємо лише фрагментарними даними, частково поданими вище. Станом на середину весни 1918 р. за попередньою інформацією на дні моря могло знаходитися близько 40 тіл, більшість 3 яких не могли підняти через приблизно встановлену локацію (обабіч Платонівського молу і в районі Воронцовського маяка) та брак технічних можливостей, насамперед відсутності потрібних рибальських сіток, якими мали витягнути трупи закатованих на берег. 3 цієї причини голова військово-морського суду виїжджав до Бугазу, але й там його спіткала невдача, відтак роботи призупинилися. Не ідеально склалася ситуація й з заявами родичів щодо зниклих осіб, позаяк частина 3 них не мешкала в Одесі, а багато одеситів побоювалися повернення більшовиків, тому воліли не оприлюднювати своїх прізвищ. У слідчій справі містилися матеріали, які підтверджували чутки про спалення в пароплавних пічках окремих жертв більшовицького

${ }^{77}$ Одесские новости. 1918.

13 апреля; Родная страна. 1918. 2 апреля, 7 апреля. терору $^{77}$.

Отже, підсумуємо. У радянській системі створення шаблонних схем революційних подій 1917-1918 рр. на півдні України крейсер «Алмаз» посідав вагоме місце, що мало продемонструвати активну участь матросів Чорноморського флоту в підготовці та здійсненні більшовицького збройного повстання й встановлення Одеської радянської республіки. При цьому йому планувалася роль «південної «Аврори»», котра мала символізувати схожі тенденції в «боротьбі прогресивних сил країни проти буржуазії і контрреволюції» у великих портових містах колишньої імперії. Формуванню героїчного іміджу екіпажу крейсера могло завадити поширення чуток про перетворення його на місце екзекуцій з боку матросів, тому в радянській історіографії воліли уникати комплексного вивчення даної сторінки історії революції в Одесі, обмежуючись лише констатацією факту відсутності конкретних доказів на початковому етапі пошуку загиблих.

Натомість джерельна база 3 проблеми є доволі репрезентативною, вона представлена архівними документами, матеріалами преси і спогадами, й дозволяє зробити значно ширші узагальнення. «Алмаз» ще до початку більшовицького збройного повстання січня 1918 р. став місцем утримання й фізичного знищення офіцерів армії УНР. Дана тенденція знайшла своє продовження і після створення Одеської радянської республіки, а задля ліквідації противників нової влади використовувався й лінкор «Синоп». Значна кількість наративних джерел дає підстави вважати, що одним 3 видів вбивства затриманих стало спалення в корабельній пічці, що унеможливлювало віднайдення їхніх залишків та документацію злочинів. Іншими варіантами позбавлення життя противників більшовицької влади й випадкових жертв «червоного» терору стали розстріли та затоплення людей як на самому кораблі, так $\mathrm{i}$ поблизу стоянки пароплавів.

Вперте поширення чуток про перетворення крейсера у головну катівню Одеси не лише робило військовий корабель символом 
страху для мешканців міста, але й змушувало місцеву владу приділяти чималу увагу вивченню ситуації навколо нього. Станом на сьогодні можна оперувати цифрою близько 40 закатованих, тіла яких були знайдені на дні моря. Головними локаціями пошуку трупів стали Платонівський мол і Воронцовський маяк, визначені за допомогою свідчень очевидців, які лише частково допомогли встановити прізвища вбитих. Але й до сьогодні усі обставини пошукових робіт залишаються нез'ясованими, що створює сприятливе підгрунтя для підживлення окремих міфів революції.

\section{References}

Achkanov, H. (1927). Ot Fevralia k Oktiabru. Oktiabr' na Odeshchine. Sb. Statey i vospominaniy k 10-letiu Oktiabria. Odesa. 1-46.

Faytelberg-Blank, V., Savchenko V. (2008). Odessa v epokhu voyn I revoluciy. 1914-1920. Odessa: Izdatielstvo «Optimum». 336.

Grazhdanskaya voyna v Rossii: Chernomorskiy flot (2002). Moskva: OOO Izdatelstvo AST. 544.

Hrycenko, I. V. (2015). Ukrains'kyi derzhavnyi flot v 1917-1919 rr.: istoriya yoho stanovlennya, viys'kovo-politychnoyi borot'by ta zanepadu. Kyiv: Vydavec' Oleh Filuk. 232.

Hryshko, H. (1930). 1917 rik v Odesi (Spomyny z chasiv vyzvolnykh zmahan'. Rozbudova naciyi. Ch. 7-8. 178-187.

Hryshko, H. (1930). 1917 rik v Odesi (Spomyny z chasiv vyzvolnykh zmahan'. Rozbudova naciyi. Ch. 11-12. 281-292.

Konovalov, V. (1963). Podvig "Almaza”. Odesa: Odesskoye knizhnoie izdatelstvo. 261.

Konovalov, V. (1989). Podvig "Almaza": dokumentalnaya povest'. 2-e izd., pererab. i dop. Odesa: Mayak. 224.

Mysechko, A. I. (2006). Do istoriyi ukrains'kogo kozactva v Odesi v period diyalnosti Central'noyi Rady (berezen' 1917 - kviten' 1918). Zapysky istorychnoho fakul'tetu. Odes 'kyi nacionalnyi universytet imeni I. I. Mechnykova. Odesa: Astroprynt. Vyp. 17. 191-196.

Odesskiye novosti (1918).

Omelyanovych-Pavlenko, M. (2002). Spohady ukrains'koho komandarma. Kyiv: Planeta ludey. 460.

Poplavs'kyi, O. O. (2012). Represiyi i terror yak osnova bil'shovyckoyi vlady v novostvorenykh radians'kykh respublikakh Pivdnya Ukrainy na pochatku 1918 r. Naukovi praci istorychnoho fakul 'tetu Zaporiz'koho nacionalnoho universytetu. Zaporizhzhya: ZNU. Vyp. XXXIII. 80-86.

Pylyshenko, V. (1977). Chjrnomorci v Ukrayins'kiy revoluciyi. Almanakh Ukrains'koho narodnoho soyuzu na 1977 rik. Dzhersi-Siti - New-York: Vydavnyctvo "Svoboda". Richnyk 67. 22-28.

Rodnaya strana (1918).

Shklyaev, I. N. (2002). Istoriya Odesskoy GUBCHK. 1917-1922 gg. Monografiya. Odessa: Studiya "Negociant". 103.

Shklyaev, I. N. (2004). Odessa v smutnoie vremya. Odessa: Studiya "Negociant". 158.

Shyshko, O. H. (2012). Dyktatura Muravyova v Odesi. Intelihenciya $i$ vlada. Hromads'ko-politychnyi naukovyi zbirnyk. Seriya: Istoriya. Odesa: Astroprynt. Vyp. 24. 218-229.

Shyshko, O. H. (2011). "Odes'ka radyans'ka respublika" : polityka teroru. Intelihenciya i vlada. Hromads 'ko-politychnyi naukovyi zbirnyk. Seriya: Istoriya. Odesa: Astroprynt. Vyp. 22. 168-178.

Vedomosti Odesskogo gradonachalstva (1918). 
Vilne zhyttia (1918).

Yuzhnaya mysl (1918).

Zahoruyko, V. (1962). "Pivdenna "Avrora". Chornomors'ka komuna. 11 lystopada.

\section{Taras Vintskovskyi}

\section{BLOODY "ALMAZ": DE/CONSTRUCTION OF ONE REVOLU- TION MYTH IN ODESA}

In Soviet historical science during 1960s-1980s a traditional stereotype of perception of the cruiser "Almaz" as "Southern Aurora" was formed, which had to symbolize similar tendencies of the revolutionary progress in 19171918 in Baltic and Black Sea Fleets. The role of the steamship crew in events of the Russian and the Ukrainian revolutions in a limited period of time is analyzed in the article.

In January 1918, the Bolshevist armed insurrection took place in Odesa, active participation in the preparation of which was played by part of sailors and officers of the cruiser "Almaz". During existence of the Odesa Soviet republic new authorities used the practice of the "red" terror, the symbol of which was "Almaz". As the result of the detention and physical liquidation of people of various categories on the cruiser and at moorings of other warships, thus spreading a variety of rumors, authorities of local self-government attempted to take control of the situation in order to make facts of self-trial impossible. But judicial and investigational institutions were able to investigate the circumstances of the detention of prisoners and their subsequent fate fully only after the restoration of the Ukrainian National Republic governance in Odesa. Their conclusions dispel the heroic image of the cruiser created by Soviet historiography.

Key words: revolution, UPR, Odesa, the Bolsheviks, «red» terror, cruiser «Almaz», city counsil, Odesa Ukrainian City Council. 